\title{
THE TEETH OF TIME: PIERRE HADOT ON MEANING AND MISUNDERSTANDING IN THE HISTORY OF IDEAS ${ }^{1}$
}

\author{
PIERRE FORCE
}

ABSTRACT

The French philosopher and intellectual historian Pierre Hadot (1922-2010) is known primarily for his conception of philosophy as spiritual exercise, which was an essential reference for the later Foucault. An aspect of his work that has received less attention is a set of methodological reflections on intellectual history and on the relationship between philosophy and history. Hadot was trained initially as a philosopher and was interested in existentialism as well as in the convergence between philosophy and poetry. Yet he chose to become a historian of philosophy and produced extensive philological work on neo-Platonism and ancient philosophy in general. He found a philosophical rationale for this shift in his encounter with Wittgenstein's philosophy in the mid-1950s (Hadot was one of Wittgenstein's earliest French readers and interpreters). For Hadot, ancient philosophy must be understood as a series of language games, and each language game must be situated within the concrete conditions in which it happened. The reference to Wittgenstein therefore supports a strongly contextualist and historicist stance. It also supports its exact opposite: presentist appropriations of ancient texts are entirely legitimate, and they are the only way ancient philosophy can be existentially meaningful to us. Hadot addresses the contradiction by embracing it fully and claiming that his own practice aims at a coincidence of opposites (a concept borrowed from the Heraclitean tradition). For Hadot the fullest and truest way of doing philosophy is to be a philosopher and a historian at the same time.

Keywords: Hadot, Wittgenstein, coherence, misunderstanding, objectivity, exegesis, philology, rhetoric, coincidentia oppositorum

The French philosopher and intellectual historian Pierre Hadot (1922-2010) became known in the United States thanks to Arnold Davidson, who introduced him to the English-speaking public in a 1990 Critical Inquiry article and called him the single most important influence behind the later Foucault and his concept of the care of the self. ${ }^{2}$ His fame in his own country came a few years later, with the publication of a book entitled Qu'est-ce que la philosophie antique ${ }^{3}$ In it Hadot developed an opinion he had held for a long time, namely that ancient philosophy was primarily a set of concrete practices aimed at shaping the soul, and that

1. Thanks to Sandra Laugier, Samuel Moyn, Melvin Richter, and Dorothea von Mücke for comments and suggestions.

2. Arnold Davidson, "Spiritual Exercises and Ancient Philosophy: An Introduction to Pierre Hadot," Critical Inquiry 16 (1990), 475-482. See Michel Foucault, History of Sexuality, transl. Robert Hurtley (New York: Vintage Books, 1988-1990, III.

3. Pierre Hadot, Qu'est-ce que la philosophie antique? (Paris: Gallimard, Folio Essais, 1995). 
ancient philosophers were much more interested in pursuing this goal than they were in achieving doctrinal coherence. Very few studies of Hadot's work have been published so far, aside from Davidson's articles and prefaces. ${ }^{4}$ The first colloquium dedicated to Hadot's work, organized by Arnold Davidson, Jean-Charles Darmon, and Frédéric Worms, took place at the École normale supérieure in 2007. Hadot himself was in attendance and spoke about a broad range of topics. He was in attendance again and made some brief comments at a small event on the occasion of the publication of the proceedings, on April 12, 2010. ${ }^{5}$ This was his last public appearance. He died on April 24, 2010 at the age of 88 .

Up until very recently, in the small number of studies that did mention him, Hadot was almost always considered in relation to Foucault. ${ }^{6}$ Yet as Davidson noticed in 1990, aside from Hadot's influence on Foucault, one aspect worthy of attention was "a reflection on the methodological problems one faces in studying the history of thought." Hadot never made a systematic exposition of his method (this would have gone against his understanding of philosophy itself) but in prefaces, interviews, footnotes, and digressions, he expressed himself forcefully on a number of issues that are familiar to intellectual historians, including the relationship between philosophy and history and the translation of past conceptual schemes into modern ones. He also claimed intriguingly that to write the history of thought is "to write the history of misunderstandings (contresens)." ${ }^{\text {" Hadot developed a }}$ distinctive voice as a philosopher and intellectual historian, even though he had no part in the debates surrounding the Cambridge school ${ }^{9}$ or Koselleck's history of concepts. ${ }^{10} \mathrm{He}$ was, nonetheless, indirectly connected with Begriffsgeschichte through his engagement with Hans Blumenberg's philosophical anthropology ${ }^{11}$ and through his critique of Gadamer's hermeneutics. ${ }^{12}$ The most important event in his intellectual development was his encounter with Wittgenstein's philosophy in the mid-1950s, long before anyone else in France was paying attention to this

4. Pierre Hadot, Philosophy as a Way of Life, edited with an introduction by Arnold I. Davidson, transl. Michael Chase (Oxford: Blackwell, 1995).

5. L'Enseignement des antiques, l'enseignement des modernes, ed. Arnold Davidson and Frédéric Worms (Paris: Editions rue d'Ulm/Presses de l'École normale supérieure, 2010). Video recording of the event at: http://www.diffusion.ens.fr/video_stream/2010_04_12_hadot.mov (accessed October 1, 2010).

6. See Cory Wimberly, "The Joy of Difference: Foucault and Hadot on the Aesthetic and the Universal in Philosophy," Philosophy Today 53, no. 2 (2009), 191-202; Thomas Flynn, "Philosophy as a Way of Life: Foucault and Hadot," Philosophy and Social Criticism 31, nos. 5-6 (2005), 609-622.

7. Davidson, "Spiritual Exercises and Ancient Philosophy," 275. See Davidson's discussion of Hadot's method in Philosophy as a Way of Life, 2-19.

8. Pierre Hadot, The Veil of Isis: An Essay on the History of the Idea of Nature, transl. Michael Chase (Cambridge: Harvard University Press, 2006), 17 (Le Voile d'Isis: Essai sur l'histoire de l'idée de nature [Paris: Gallimard, 2004]).

9. See Quentin Skinner, "Meaning and Understanding in the History of Ideas," History and Theory 8, no. 1 (1969), 3-53; Skinner, Visions of Politics (Cambridge, UK: Cambridge University Press, 2002), I.

10. Otto Brunner, Werner Conze, and Reinhart Koselleck, Geschichtliche Grundbegriffe: Historisches Lexikon zur politisch-sozialen Sprache in Deutschland, 8 vols. (Stuttgart: Klett, 1972-1997).

11. See Hadot, The Veil of Isis, $\mathrm{x}$-xi. On Blumenberg and Begriffsgeschichte, see Hans Erich Bödecker, Begriffsgeschichte, Diskursgeschichte, Metapherngeschichte (Göttingen: Wallstein Verlag, 2002).

12. See Hadot, Le Voile d'Isis, 16. 
philosopher. What made Hadot unusual in the French intellectual landscape was that he was a philosopher and a historian at the same time: not someone who occupied a middle ground between history and philosophy; not someone who made a conventional call for a dialogue between the two disciplines; but someone who made the seemingly implausible claim that his work was both entirely historical and entirely philosophical. In this article, I would like to propose an analysis and a critical assessment of this claim.

\section{HADOT'S UNCONVENTIONAL CAREER}

Born in Paris on February 21, 1922, Hadot became professor of Hellenistic and Roman Thought at the Collège de France in 1982 and taught there until his retirement in 1991. He was elected professor with the support and encouragement of Michel Foucault, who had himself been on the Collège de France faculty since 1970. Like Foucault in his later years, Hadot had an interest in the Hellenistic tradition of studying the lives of philosophers. In this tradition, telling the story of a philosopher's life is philosophically meaningful. Hadot seems to have been a very private and discreet person. However, in his later years, he came forward with significant biographical information about himself. These autobiographical disclosures, some of them quite intimate, were clearly intended as philosophical statements. They can be found in a series of conversations with Jeannie Carlier and Arnold Davidson, first published in France in 2001, ${ }^{13}$ in the public conversation between Hadot and Davidson at the École normale supérieure in 2007 (published in 2010), ${ }^{14}$ and in the preface Hadot wrote in 2004 for a new edition of his work on Wittgenstein. ${ }^{15}$

Hadot worked in relative obscurity for most of his life, and his career did not follow the standard trajectory. The most prominent philosophers who came of age in France in the 1950s had very similar career paths: Michel Foucault, Jacques Derrida, and Gilles Deleuze were all students at the École normale supérieure and they were all tutored by Louis Althusser for the agrégation in philosophy. Hadot was neither a normalien nor an agrégé. Born into a lower-middle-class family, he grew up in Reims, in the Champagne region of France. His father, who had no formal education, rose through the ranks to become a manager in the Piper Heidsieck wine company. His maternal grandfather was a man from Lorraine who had opted for French citizenship following the annexation of the province by Germany in 1871. Hadot's cousins from Lorraine spoke little or no French, even though Lorraine had been returned to France in 1918, and he communicated with them in German. A quasi-native familiarity with German language and culture was an important part of Hadot's intellectual persona. Hadot's mother was an extremely

13. Pierre Hadot, The Present Alone is Our Happiness: Conversations with Jeannie Carlier and Arnold I. Davidson, transl. Marc Djaballah (Stanford: Stanford University Press, 2009) (La Philosophie comme manière de vivre: Entretiens avec Jeannie Carlier et Arnold I. Davidson [Paris: Albin Michel, 2001]).

14. "Entretien entre Pierre Hadot et Arnold I. Davidson," École normale supérieure, Paris, June 1, 2007, in Davidson and Worms, ed., L'Enseignement des antiques, l'enseignement des modernes, 19-34.

15. Pierre Hadot, Wittgenstein et les limites du langage (Paris: Vrin, 2004). 
devout Catholic who insisted that each of her three sons should become a priest, and did indeed get her wish. Hadot was ordained in 1944 but was never interested in becoming a parish priest. He joined the CNRS (the newly established national research institute) in 1949 and left the priesthood in 1952 to get married. A divorce ensued a few years later. In 1966 he married a German-born scholar, Ilsetraut Marten, with whom he co-authored a volume on the commentary of Epictetus by Simplicius. ${ }^{16}$ Looking back in his old age at his formative years, Hadot described his departure from the Christian faith as a very slow process, which did not get in the way of his friendships with members of the Catholic clergy. He credited his training as a priest for his familiarity with Latin and Greek literature, and also for his early interest in philosophy, which went beyond Thomism and included Bergson, who was widely read in Catholic seminaries in the 1930s. Hadot initially considered writing his doctoral dissertation on Heidegger and Rilke under the direction of Jean Wahl (1888-1974), the very active and prominent Sorbonne professor who had spent World War II in exile in the United States after escaping from the Drancy internment camp, and co-founded the École Libre des Hautes Études in New York in 1942. Instead, he chose to work under the direction of a Jesuit scholar, Paul Henry (1906-1984), and to follow Henry's suggestion that he should produce a critical edition of Marius Victorinus, a fourth-century neo-Platonic philosopher. "I became a historian following my encounter with the Jesuit scholar Paul Henry," Hadot said in 2007. ${ }^{17}$ Jean Wahl was reportedly very upset with this "defection." ${ }^{18}$ In accordance with the French academic tradition of the time, Hadot spent twenty years of his life working on this edition before presenting it as a thèse d'Etat. He became a directeur d'études in the fifth section (religious studies) of the École pratique des hautes études in 1964, and taught Latin and Greek patristics there until his election to the Collège de France.

In his autobiographical statements, Hadot does not go into much detail regarding the reasons for his choice of a dissertation topic. He seems to imply that his natural inclination was modern philosophy and that he made a conscious decision to go against this inclination by working on an antiquarian topic. Marius Victorinus was not particularly interesting philosophically and was also unusually difficult to make sense of. However, Hadot always made it clear that he did not regret those twenty years spent elucidating a minor and nearly incomprehensible author, because this experience taught him "how to read texts scientifically." ${ }^{19}$ Before he started to work on Marius Victorinus, Hadot could read Latin and Greek because of the humanist education he had received as a seminarian, but he knew nothing of the techniques of philology and had very little sense of history. Neo-Platonic philosophy was an acquired taste, as was the practice of philology. Hadot thought of himself and presented himself as a philosopher who chose to become a historian.

One of Hadot's tasks as a CNRS researcher in the 1950s was to produce content summaries of scholarly journals coming from abroad. It is in this context that he was

16. Ilsetraut and Pierre Hadot, Apprendre à philosopher dans l'Antiquité : L'enseignement du Manuel d'Epictète et son commentaire néo-platonicien (Paris: Livre de poche, 2004).

17. Davidson and Worms, ed., L'enseignement des antiques, l'enseignement des modernes, 32.

18. Ibid., 33.

19. Ibid. 
initially exposed to Wittgenstein, an author who was virtually unknown in France at the time and was not translated until 1961 by Pierre Klossowski (Hadot made a complete French translation of the Tractatus for his own use in the late 1950s). At the invitation of Jean Wahl, Hadot gave a public talk on the Tractatus on April 29,1959 . The location was the Collège philosophique, the go-to place for aspiring and established philosophers alike because of its perceived ability to confer social prestige and scholarly recognition at the same time. Jean Wahl immediately accepted the paper for publication in the Revue de métaphysique et de morale.$^{20}$ This was followed by two articles in Critique the same year (one on the Tractatus, and the other on the Philosophical Investigations ${ }^{21}$ ), and yet another one two years later in the Revue de métaphysique et de morale on philosophy and language games.22 Hadot sent the first Critique article to Elizabeth Anscombe, Wittgenstein's student, friend, and commentator. She replied that it gave "an excellent popular account" of Wittgenstein's work. She added that it had "the unusual merit of presenting an account which seems to be derived purely from what Wittgenstein said and not from what Russell or the Vienna Circle philosophers held him to mean." ${ }^{23}$ Hadot must have been touched by these comments, anxious as he was to remain faithful to the intent of the thinkers he was interpreting (more on this later).

Hadot's articles on Wittgenstein were collected in a small volume published by Vrin in 2004. In the preface he wrote for this edition, Hadot uses the language of conversion narratives to present his encounter with Wittgenstein..$^{24}$ The analysis of language he found in Wittgenstein was "revolutionary." ${ }^{25}$ It provoked "an overturning" ${ }^{26}$ (bouleversement) of his philosophical views. Finally, and this is a crucial point for Hadot: "All kinds of perspectives opened up for me in my work as a historian of philosophy." ${ }^{27}$ Whether or not the epiphany described here was an actual event, it provides a turning point in the autobiography and serves the same symbolic purpose as the Tolle lege scene in Augustine's Confessions. What are these new perspectives? They can be summarized in a somewhat cryptic formula, taken from the Philosophical Investigations: "Understanding a sentence is much more akin to understanding a theme in music than one may think." 28

20. Pierre Hadot, "Réflexions sur les limites du langage à propos du Tractatus LogicoPhilosophicus de Wittgenstein," Revue de métaphysique et de morale 63 (1959), 469-484.

21. Pierre Hadot, "Wittgenstein philosophe du langage -I" Critique 149 (1959), 866-881; Hadot, "Wittgenstein philosophe du langage -II" Critique 150 (1959), 972-983.

22. Pierre Hadot, "Jeux de langage et philosophie," Revue de métaphysique et de morale 67 (1962), 330-343.

23. Letter from Elizabeth Anscombe to Pierre Hadot, October 10, 1959, in Hadot, Wittgenstein et les limites du langage, 106.

24. On philosophy and conversion, see Pierre Hadot, article on "Conversion," Encyclopaedia Universalis, 20 vols. (Paris: Encyclopaedia Britannica, 1968).

25. Hadot, Wittgenstein et les limites du langage, 11.

26. Ibid.

27. Ibid.

28. Wittgenstein, Philosophical Investigations (PI), transl. G. E. M. Anscombe (New York: MacMillan, 1953), §527, quoted by Hadot in Wittgenstein et les limites du langage, 11. 


\section{UNDERSTANDING A SENTENCE IS LIKE UNDERSTANDING A MUSICAL THEME}

Hadot credits Wittgenstein for showing him that the primary function of language is not to name objects or designate thoughts. Wittgenstein illustrates this point by describing the way one speaks of a musical theme. On the one hand, words seem unable to convey what a particular musical theme is about: "One would like to say 'Because I know what it's all about.' But what is it all about? I should not be able to say." ${ }^{29}$ On the other hand, using words is in fact possible. For instance, one may make comparisons "with something else which has the same rhythm" and say things like “'Don't you see, this is as if a conclusion were being drawn' or 'This is as it were a parenthesis." ${ }^{30}$ Wittgenstein's use of a musical example supports his polemical stance against a mentalist conception of language that associates words and sentences with inner images or feelings and assumes that understanding a sentence means having access to those inner images or feelings. If one assumes the reality of those inner images or feelings, it should be possible to describe them in different ways and still designate the same images or feelings. Yet for Wittgenstein the opposite is true: understanding a musical theme means understanding something that only this particular musical theme says. This is generally accepted in the case of music, because it is usually assumed that music does not refer to anything beyond itself. Wittgenstein's paradoxical point is that what is true of music is in a sense true of language in general.

In the Lectures on Aesthetics, Wittgenstein refers to the use of the phrase "A man is musical." ${ }^{\prime 1}$ He notices that we do not use this phrase to designate someone who says "Ah!" when a piece of music is being played. This would be tantamount to calling a dog musical because it wags its tail when music is being played. A man is musical when he is able to play the language game that consists in showing his appreciation of music. At first, it seems very difficult (if not impossible) to find words to describe what is unique about a particular piece, but experience shows that those who have good aesthetic judgment manage to find the words (anything that works will do here) and actually agree with others (who have equally good judgment) that these words are indeed well chosen. The same analysis could be made of a game that would consist in describing the aroma of coffee..$^{32}$ This neither proves nor requires the existence of something beyond the words themselves that would make the agreement possible. It simply describes a language game that consists in agreeing (or disagreeing) about the characterization of a musical theme or a sentence.

For Wittgenstein however, the musical analogy captures only one aspect of what is going on in understanding a sentence:

29. PI, 527.

30. Ibid.

31. Ludwig Wittgenstein, Lectures and Conversations on Aesthetics, Psychology and Religious Belief (LA), ed. Cyril Barrett (Oxford: Blackwell, 1966), 17.

32. PI, 610. 
We speak of understanding a sentence in the sense in which it can be replaced by another which says the same; but also in the sense in which it cannot be replaced by another. (Any more than one musical theme can be replaced by another.)

In the one case the thought in the sentence is something common to different sentences; in the other, something that is expressed only by these words in these positions. (Understanding a poem).$^{33}$

On the one hand, understanding a sentence means understanding what is unique about this sentence. On the other hand, it means understanding something that could be expressed in different ways. For Wittgenstein, these are not two separate and unrelated meanings of "understanding." On the contrary, "these kinds of use of "understanding' make up its meaning, make up my concept of understanding."."34

This analysis of "understanding" is fundamentally important for Hadot because it captures the contradiction that is at the heart of historical understanding in general and intellectual history in particular. On the one hand, a historian who strives to say what is unique about a particular utterance will be very careful to avoid anachronistic interpretations. As a philosopher, Wittgenstein was not particularly interested in history, but Hadot sees his philosophy of language as supporting a strongly historicist stance. As Wittgenstein puts it, "what belongs to a language game is a whole culture." 35 If you want to describe musical taste, "you have to describe whether children give concerts, whether women do or whether men only give them, etc., etc." In other words, "to describe a set of aesthetic rules fully means really to describe the culture of a period." ${ }^{36}$ For Hadot, this is the philosophical foundation of the historian's duty "to aim for objectivity and, if possible, for truth. ${ }^{37}$ It is of paramount importance to avoid anachronistic readings and to resituate the works "within the concrete conditions in which they were written." 38 This means looking at philosophical, rhetorical, or poetic traditions, as well as material conditions, including the educational and social milieu, and the material constraints involved in committing something to writing. ${ }^{39}$ Hadot's seemingly old-fashioned allegiance to strict norms of objectivity is not grounded in the belief that reading old texts in context will somehow give us access to "things as they actually happened." In Wittgenstein's terms, this would be just as absurd as saying that understanding a musical theme means understanding the things it describes. What makes a strictly objective approach necessary is the need to play the language game in the right way and to do justice to what is unique about a particular utterance or set of utterances. An example of Hadot's approach is his adamant rejection of psychological readings of ancient philosophers. Conventional readings of the Meditations of Marcus Aurelius have emphasized what seems to give us access to his interiority: "the hesitations, contradictions and strugglings of a man abandoned to solitude." ${ }^{40}$ However, what we perceive as psychological reality or

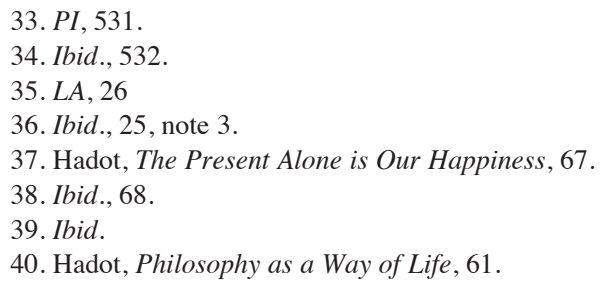


mental content is simply an anachronistic projection of modern categories. An objective reader will be "rather astounded by the firmness of the thought and the technical nature of the philosophical vocabulary one encounters from beginning to end of the Meditations." ${ }^{41}$ The language game played in the Meditations is not the Romantic expression of a self; it is the rehearsal of Stoic arguments aimed at achieving peace of mind.

On the other hand, as Wittgenstein puts it, "the thought in the sentence is something common to different sentences." What a text from the past says can be said in different words without distortion or betrayal: the same things can be said in many different ways. For Hadot, this other aspect of the meaning of "understanding" is the philosophical foundation of deliberately presentist appropriations of old texts, as well as freewheeling cross-cultural comparisons. Painstaking reconstruction of the meaning of an ancient author always yields the same realization: "The meaning intended by the ancient author is never current (actuel). It is ancient, and that is all there is to it." ${ }^{42}$ However, ancient philosophies like Epicureanism or Stoicism describe some basic attitudes that are perfectly valid today, once they have been detached from their historical context. Similarly, Hadot is comfortable drawing parallels between Pyrrho and the Chinese philosopher Lie Yukou, who both found wisdom in taking care of mundane tasks and living their lives as everybody else did. ${ }^{43}$ "In the final analysis," Hadot argues, "there are relatively few possible attitudes with respect to our existence, and, irrespective of historical influence, different civilizations have been led to similar attitudes." ${ }^{44}$

\section{THE INCOHERENCE OF ANCIENT PHILOSOPHY}

Hadot claims that one of the essential lessons he drew from his encounter with Wittgenstein's thought is the paramount importance of literary form in the practice of philosophy. The prime example in that regard is the Tractatus itself. This is why, in the small volume that gathers his own articles on Wittgenstein, Hadot found it necessary to include an article by Gottfried Gabriel on the significance of literary form in the Tractatus. ${ }^{45}$ Gabriel shows that Wittgenstein hated Russell's preface to the Tractatus because it gave a paraphrase of the logical propositions of the work. Russell understood Wittgenstein's sentences in the sense in which they could be replaced by others that said the same, but not in the sense in which they could not be replaced by another. Gabriel refers to the famous letter to von Ficker where Wittgenstein writes that the Tractatus is both philosophical and literary, and insists that nothing should be changed, not even the spelling. The "ethical sense" of the Tractatus cannot be taught. It can only be shown and experienced. It is the experience of "bumping against the wall of language." The aphorism is the ideal vehicle for this experience. It puts forward propositions that are neither

41. Ibid.

42. Hadot, The Present Alone is Our Happiness, 68 (translation modified).

43. Ibid., 69-70.

44. Ibid., 69 (translation modified).

45. Gottfried Gabriel, "La logique comme littérature? Remarques sur la signification de la forme littéraire chez Wittgenstein," in Hadot, Wittgenstein et les limites du langage, 111-126 ("Logik als Literatur? Zur Bedeutung des Literarischen bei Wittgenstein,” Merkur 32 [1978], 353-362). 
"true" or "not true" (in the sense of logical and empirical truth) but nonsensical. They point the way toward a "just" perception of the world (amazement that the world is). This cannot be said; it can only be shown. In that sense, extracting a doctrinal content from the aphorisms of the Tractatus, as Russell did, misses the point of the entire book.

This is why philological skills and a historical approach are necessary for the understanding of philosophy in general: "The primary quality of a historian of philosophy, and probably of a philosopher, is to have a historical sense." ${ }^{46}$ Hadot claims that a fundamental principle in his approach to the history of philosophy is a principle he learned from his dissertation advisor, Paul Henry, who was first and foremost a philologist. Historians of philosophy are in the business of comparing doctrines and looking for influences and traditions of thought. Yet Hadot says, "The great idea I retained from Paul Henry is that only literal and not doctrinal comparisons are conclusive. ${ }^{47}$ It is easy to make comparisons based on vague similarities or commonplaces that can be found in many authors. However, "this proves nothing at all." 48 One must look for objective evidence such as repeated literal borrowings, or the appropriation of very specific conceptual structures expressed in a recognizable vocabulary, such as the ternary scheme that Epictetus and Marcus Aurelius have in common. ${ }^{49}$ Here again, the rule is to understand a sentence in the way in which it cannot be replaced by another.

Hadot presents his encounter with Wittgenstein as having given a philosophical foundation to the philological approach he had been practicing since the beginning of his doctoral research. In addition, doing philology in this spirit allowed him to solve a problem that puzzled conventional historians of philosophy: the apparent incoherence of ancient philosophers. There are countless contradictions in Plato and Aristotle, and a traditional exercise for historians of philosophy has been to account for these contradictions by reconstructing the coherence of their doctrines or supposing an evolution in their thinking. However, according to Hadot, this overlooks the nature of ancient philosophy as a concrete practice, which was grounded in the oral exercise of question and answer:

Although every written work is a monologue, the philosophical work is always implicitly a dialogue. The dimension of the possible interlocutor is always present within it. This explains the incoherencies and contradictions which modern historians discover with astonishment in the work of ancient philosophers. In philosophical works such as these, thought cannot be expressed according to the pure, absolute necessity of a systematic order. Rather, it must take into account the level of the interlocutor, and the concrete tempo of the logos in which it is expressed. It is the economy proper to a given logos which conditions its thought content, and it is the logos that constitutes a living system which, in the words of Plato, "ought to have its own body ... it must not lack either head or feet; it must have a middle and extremities so composed as to suit each other and the whole work" (Phaedrus, $264 c) .^{50}$

46. Hadot, The Present Alone is Our Happiness, 74 (translation modified).

47. Ibid., 66 .

48. Ibid.

49. Ibid.

50. Hadot, Philosophy as a Way of Life, 105. 
When Greek philosophers spoke of logos, they did refer to a coherent discourse, but it was the coherence of a particular discourse at a particular time: the response to one specific question. As Hadot puts it, "each logos is a 'system' but the totality of logoi written by an author does not constitute a system." ${ }^{51}$ It is therefore futile to look for the coherence of Aristotle's philosophy as a whole, or to try to divide it up into successive coherent periods. Thus Hadot refers approvingly to the classic work of Ingemar Düring, ${ }^{52}$ who showed that Aristotle approaches a problem or a group of problems over and over again from different angles. Each new treatment begins with the phrase: "Now taking a different starting point ..." and arrives at a conclusion that is not necessarily consistent with the previous treatment. ${ }^{53}$ According to Hadot, Düring's description "can in fact apply, mutatis mutandis, to almost all the philosophers of antiquity." 54

From Hadot's perspective, the concept of mentalité collective, used by some historians, proceeds from the same fallacy as the assumption of coherence in an individual author. In a brief, polemical piece initially published in the bulletin of the Collège de France in 1984, Hadot criticized those historians who think they can describe the mentalité of an entire period like the age of Marcus Aurelius. ${ }^{55}$ These descriptions, he argued, are based on a "methodological mistake." ${ }^{56}$ What was written in the second century CE was determined by a multiplicity of local and national traditions of a religious, political, philosophical, and rhetorical nature, and not by the spirit of the age. There is no such thing as the collective mentality of the Roman Empire of the second century. One can only speak of discrete traditions and practices.

This is where Hadot's most important and famous insight about ancient philosophers comes in: that their goal was, in Victor Goldschmidt's words, "to form, more than to inform." ${ }^{57}$ Hadot repeated this formula in various places, and the fact that he borrowed it from another scholar shows that he did not have any proprietary attitude about this discovery. He went out of his way to show that he shared this view of philosophy as therapy of the soul with scholars such as Paul Rabbow, ${ }^{58}$ André-Jean Voelke, ${ }^{59}$ or Juliusz Domański ${ }^{60}$ According to Hadot, some but not all philosophers of the early modern and modern periods continued this tradition, and Wittgenstein is a prime example of the practice of philosophy as a way

51. Ibid.

52. Ingemar Düring, Aristoteles: Darstellung und Interpretation seines Denkens (Heidelberg: C. Winter, 1966).

53. Ibid.

54. Hadot, Philosophy as a Way of Life, 106.

55. Pierre Hadot, "La notion de mentalité collective," in Etudes de philosophie ancienne (Paris: Les Belles Lettres, 1998), 115-121.

56. Ibid., 116.

57. Pierre Hadot, Exercices spirituels et philosophie antique (Paris: Albin Michel, 2002), 46, quoting Victor Goldschmidt, Les Dialogues de Platon: structure et méthode dialectique (Paris: Presses Universitaires de France, 1963), 3.

58. Paul Rabbow, Seelenführung: Methodik der Exerzitien in der Antike (Munich: Kösel-Verlag), 1954.

59. André-Jean Voelke, La philosophie comme thérapie de l'âme: études de philosophie hellénistique (Paris: Cerf, 1993).

60. Juliusz Domański, La philosophie, théorie ou manière de vivre? Les controverses de l'antiquité à la renaissance (Fribourg: Editions universitaires; Paris: Cerf, 1996). 
of life. In that sense, for Hadot, the classic debate about the discrepancy between the Wittgenstein of the Tractatus and the Wittgenstein of the Philosophical Investigations is moot for two reasons: first, because the assumption of doctrinal coherence is highly questionable in general; second, because the continuity resides not in the doctrine but in the ethical stance. As Sandra Laugier points out, Hadot was one of the very first interpreters to see the "therapeutic" dimension that runs from the Tractatus to the Philosophical Investigations. ${ }^{61}$ This interpretation of Wittgenstein was later developed by Stanley Cavell, James Conant, and Cora Diamond. ${ }^{62}$ The important point for the purposes of this study is Hadot's insistence that he was not drawn to this notion of philosophy as a way of life for spiritual or ethical reasons. He did not come to the conclusion that ancient philosophy consisted mostly of spiritual exercises because he had a taste for philosophy of an edifying kind. He was drawn to this conclusion for reasons that were both conceptual and exegetical. ${ }^{63}$ As we have seen above, in the conversations with Carlier and Davidson, Hadot initially presents himself as a philosopher who chose to become a philologist. The reasons for that initial choice are not fully explained, except for the suggestion that Hadot went deliberately against his natural inclination. In the encounter with Wittgenstein, Hadot went full circle: now a philologist, he found a philosophical rationale for the practice of philology, and the insight he drew from reading Wittgenstein allowed him to solve what had traditionally been a puzzle for philologists, namely the incoherence of ancient philosophers.

\section{EXEGESIS AND MISUNDERSTANDING}

Faithfulness to the author's intent was such an essential obligation for Hadot that he used uncharacteristically strong language to criticize what he saw as relativism or arbitrariness in interpretation: "I detest those monographs which, instead of allowing the author to speak by remaining close to the text, engage in obscure speculation claiming to decode and reveal the author's tacit meaning, while the reader is left without any idea of what the thinker really "said." ${ }^{64}$ Hadot adds that "our time is fascinating for many reasons." However, "from a literary and philosophical point of view, it could be defined as the era of misinterpretation (l'ère du contresens), if not the era of the pun: on any subject, anything goes! (n'importe quoi à propos de n'importe quoi)." ${ }^{65}$

This invective against the zeitgeist is only one aspect of Hadot's position. On the one hand, misinterpretation is characteristic of the reading practices of our time. On the other hand, according to Hadot, misinterpretation has played a key role in the history of philosophy itself. Hadot first wrote about this issue in a 1968 article entitled "Philosophy, Exegesis and Misinterpretation.." ${ }^{\prime 6}$ Hadot begins with

61. Sandra Laugier, "Langage ordinaire et exercice spirituel," in Davidson and Worms, ed., L'enseignement des antiques, l'enseignement des modernes, 61-79.

62. Ibid., 61 .

63. Hadot, The Present Alone is Our Happiness, 59.

64. Pierre Hadot, La Citadelle intérieure: Introduction aux Pensées de Marc Aurèle (Paris: Fayard, 1997), 10 .

65. Ibid.

66. Pierre Hadot, "Philosophie, exégèse et contresens," in Etudes de philosophie ancienne, 3-11 
a sweeping historical assessment: by and large, from Antiquity to the present, the practice of philosophy has been based on the reading and interpretation of texts from earlier periods. In other words, the practice of philosophy has been exegetical in nature. Ancient and humanist forms of exegesis had a common purpose: the appropriation of ancient texts by the modern reader. This appropriation was carried out by various techniques, including allegory. With the advent of modern philology in the eighteenth century, traditional exegesis was discredited, and the interpretations performed by ancient and humanist exegetes were seen as anachronistic distortions of the original intent present in ancient texts. In that sense, Hadot argues, all exegesis is misinterpretation. According to Hadot, there were two sources of error in the work of pre-Enlightenment exegetes. First, they assumed that all the works of a given author formed a coherent whole, and they brought together passages taken out of context to construct a coherent doctrine out of a corpus that had no apparent coherence. An example of this practice is Plato's five-tier hierarchy of being, never mentioned in Plato's texts but constructed by his neo-Platonic interpreters. Second, pre-Enlightenment exegetes brought concepts together from disparate doctrines. For instance, Aristotle's commentators used Stoic or Platonic concepts. Such practices, especially when the text considered was a translation, were sometimes not simply distortions but outright inventions that made something out of nothing. Hadot gives the example of Augustine's reading of Psalm 115, 16 [113, 24 in the Latin Vulgate]: "The heavens are the Lord's heavens." Augustine's version of the text (in Latin, but based on the Septuagint Bible) is coelum coeli domino (the heaven of heavens belongs to the Lord). Augustine then speculates on the existence of a "heaven" as a cosmological reality he identifies with the realm of the intelligible, and he explains how to situate this heaven with respect to the heaven mentioned in Genesis. Hadot insists that, from the point of view of the Hebrew Bible, "this whole construction is based on thin air." ${ }^{\prime 67}$ As the great theorist and practitioner of the Christian exegetical method, Augustine seems to be one of Hadot's favorite targets. In his inaugural lecture at the Collège de France, Hadot mentioned the famous formula from $\mathrm{Au}$ gustine: in interiore homine habitat veritas ${ }^{68}$ (it is in the inner person that truth dwells). This formula, appropriated by Husserl in the Cartesian Meditations, is at the root of the modern concept of the subject. Yet, as Hadot shows, in crafting it, Augustine inadvertently put together two segments of sentences from the Letter to the Ephesians that were semantically unconnected in Paul's original. Hence, "a group of words whose unity was originally purely material, or, which was a misunderstanding of the Latin translator, was given a new meaning by Augustine, and then by Husserl, thus taking its place in the vast tradition of deepening the idea of self-consciousness." ${ }^{69}$

(Akten des XIV Internationalen Kongresses für Philosophie [1968], 333-339). "Philosophy, Exegesis and Creative Mistakes," in Hadot, Philosophy as a Way of Life, 71-77. Michael Chase's translation of "creative mistakes" softens the meaning of contresens, a word used by classics teachers in France to refer to a translation that misconstrues the meaning of an entire sentence-three contresens in one translation typically result in a failing grade.

67. Hadot, Philosophy as a Way of Life, 75 .

68. Augustine, De vera religione, 39.72 .

69. Hadot, Philosophy as a Way of Life, 66 [Inaugural lecture at the Collège de France, February 18, 1983]. 
If the practice of philosophy was mostly exegetical, and if all exegesis is predicated on misunderstanding, then it is the entire history of philosophy that can be written as a comedy of errors. This thought can be "somewhat frightening" modern historians. On the other hand, Hadot insists, misunderstanding has been the main engine behind the creation of new philosophical concepts. For instance, the distinction between "being" in the infinitive ( $\tau$ ò $\varepsilon \hat{\imath} v \alpha \iota)$ and "being" in the participle ( $\tau \grave{o}$ ó $v$ ) was invented by Porphyry in order to solve a difficulty posed by a passage in Plato. This distinction played a key role in the history of metaphysics up to Heidegger. "The history of the notion of being," Hadot adds, is "marked by a whole series of such creative mistakes." 71 This remark can be extended to intellectual history in general: "To write the history of thought is to write the history of misunderstandings." 72

Hadot seems to have ambivalent feelings about this fact. On the one hand he has a quasi-Voltairean take on the history of the human mind as the record of human errors. ${ }^{73}$ On the other hand he is ready to embrace it, both as a historian and as a philosopher. His 2004 book, The Veil of Isis, is the history of the successive meanings of a single saying by Heraclitus: physis kryptesthai philei (Nature loves to hide). Hadot shows that there is almost no connection between the original meaning of the sentence and the meaning it had for early modern and modern philosophers of nature. For Heraclitus, the sentence meant something like "what is born tends to disappear" (based on the early sense of physis as that which is born and dies). For early modern philosophers the saying referred to the notion of $a r$ cana naturae: the hidden secrets of nature that science sought to reveal. One may ask why Hadot felt the need to write such a history: historians want to tell stories that offer a mix of continuity and change. The saying in question has had such disparate meanings that there is arguably no point in considering them together. But precisely in this case there is a remarkable continuity: over 2,500 years, it is the exact same formula that has been interpreted and reinterpreted. The saying by Heraclitus is one of those "good maxims" that endure successive reinterpretations: "A good aphorism is too hard for the tooth of time, and is not worn away by all the centuries, although it serves as food for every epoch. Hence it is the greatest paradox in literature, the imperishable in the midst of change, the nourishment which always remains highly valued, as salt does, and never becomes stupid like salt." ${ }^{74}$ This passage from Nietzsche appears in the conclusion of The Veil of Isis, and is less a conclusion or an explanation than the reaffirmation of a puzzle. Some sentences have a remarkable staying power, but what makes their permanence possible is something of a mystery. The only thing that comes close to an explanation of this phenomenon is an allusion to Hans Blumenberg's work on myth. Hadot endorses Blumenberg's idea that certain metaphors (for instance, the

70. Hadot, "Philosophie, exégèse et contresens," 9.

71. Hadot, Philosophy as a Way of Life, 75.

72. Hadot, The Veil of Isis, 17.

73. "There is the history of opinions which is hardly anything but a collection of human errors." Voltaire, Philosophical Dictionary, "History" article, transl. H. I. Woolf (New York: Knopf, 1924).

74. Friedrich Nietzsche, Human All Too Human, transl. Paul V. Cohn (Amherst, NY: Prometheus, 2009), Part II, §168. 
nakedness of truth, nature as writing and as a book, the world as a clock) act like "prefabricated models" 75 that condition our thought in ways that remain largely invisible to us. According to Hadot, "these traditional metaphors are linked intimately with what are called commonplaces in rhetoric." " One should add that the subtitle of Hadot's book ("An Essay on the History of the Idea of Nature") can easily be misunderstood. Hadot's intent was not to write the history of a unit-idea called "Nature." It was rather to write the history of something much more concrete, namely one sentence, and one image that has often been associated with it: the unveiling of the half-naked goddess Artemis.

In his 1962 article on language games and philosophy, Hadot pointed out that the ancients had a better understanding than we do of what it is to play a language game: "For them a saying had naturally several meanings, i.e. several possible applications." 77 The rhetorical culture of antiquity was an oral culture, in which ready-made topoi were given meaning through a performance that was always singular and tied to a particular place and a particular time. We are less sensitive to these aspects, says Hadot, because philosophy is no longer practiced as "speech." ${ }^{78}$ It is now practiced "not only as writing, but as printed writing."

In the spirit of Hadot's reading of Wittgenstein, we can draw an example of what the ancients were up to from the Philosophical Investigations. Wittgenstein discusses a language game that consists in considering one face and thinking of it as timid, then courageous. This does not mean imagining that the timid-looking face would belong to someone who performed acts of courage, because such acts could be associated with any face. It means reading courage into the exact same facial expressions that indicated timidity before. Wittgenstein concludes that "the reinterpretation of a facial expression can be compared to the reinterpretation of a chord in music, when we hear it as a modulation into this, then into that key." The same musical theme is played in a different key, as the same face is seen as conveying different expressions. In the case of facial expressions, the change in meaning is performed by imagining a different context. For instance, the same smiling face can be seen as kind or cruel by imagining that the smiler "was smiling down on a child at play, or again on the suffering of an enemy." 81 The same game can be played in philosophy. Hadot points out that "once it is taken out of its original context," a philosophical formula "can change its meaning without any difficulty, i.e. be re-used in a different language game." 82

Hadot concluded the penultimate paragraph of his 1968 article on exegesis with the following statement: "It seems that we moderns have lost the comprehension of what ancient rhetoric was." ${ }^{83}$ It is remarkable that in the past forty years

75. Hadot, The Veil of Isis, xi.

76. Ibid.

77. Hadot, Wittgenstein et les limites du langage, 99.

78. Ibid.

79. Ibid.

80. PI, 536.

81. Ibid., 539.

82. Hadot, Wittgenstein et les limites du langage, 99.

83. Hadot, "Philosophie, exégèse et contresens," 10. This sentence is absent from the English translation. 
there has been a great deal of interest in the ancient and early modern rhetorical tradition, and it can be said that we now have a much better understanding of the performative aspects of ancient and humanist rhetoric. ${ }^{84}$ In a few paragraphs of his Encyclopaedia Universalis article on "Conversion," also published in 1968, Hadot gave a remarkably forward-looking summary of the issues that have since been studied by the historians of rhetoric: the art of rhetoric arose in the context of Greek and Roman judicial and political culture; the concrete goal of rhetoric was to "change the soul"; the philosophers themselves used rhetorical means to convert others to the philosophical way of life ${ }^{85}$ But precisely, from Hadot's point of view, this better understanding of rhetoric is tied to a return of allegorical exegesis in the practice of philosophy: "Contemporary philosophical discourse has once again become exegetical, and, sad to say, it often interprets texts with the same violence used by ancient practitioners of allegory." ${ }^{86}$ Reading courage into a timid-looking face would be a very good image of what ancient philosophers were doing, and in that sense the linguistic turn in contemporary philosophy recaptures something that was essential to the practice of ancient philosophy. On the other hand this exercise is a violent one because it severs all ties to what gave life to previous utterances of a particular image or sentence.

\section{CONCLUSION: WRITING HISTORY AS COINCIDENTIA OPPOSITORUM}

For Wittgenstein, "understanding a sentence" has two meanings: it refers to what can be said with other words, and what can be said only with the same words. Or rather the concept of understanding includes both meanings together.

How these two meanings of "understanding" can be held together was a fundamental problem for Hadot. In his work as a historian of philosophy, Hadot was a strict contextualist who made every effort to avoid anachronistic interpretations. At the same time, he did not hesitate to draw parallels between historically unrelated concepts like the concept of physis in Heraclitus and the concept of organic destruction in Claude Bernard ${ }^{87}$ Similarly, he had no qualms about linking Thoreau to "a kind of universal Stoicism," and "a kind of universal Epicureanism." ${ }^{88}$ In his conversations with Carlier and Davidson, Hadot described the present-minded appropriation of old concepts as a "supplement," comparable to what Aristotle said about pleasure. For Hadot, "there is always added to the effort of objectivity a supplement, a surplus, which is the possibility of finding our spiritual nourishment in it." ${ }^{89}$

As we have seen above, Hadot criticized the lack of historical sense in contemporary philosophers, but he also saw their allegorical use of old concepts as a return to an ancient exegetical tradition that was itself associated with the no-

84. The International Society for the History of Rhetoric was founded in 1977. In the French context, see Marc Fumaroli, L'Âge de l'éloquence (Geneva: Droz, 1980).

85. Hadot, Encyclopaedia Universalis, article on "Conversion."

86. Hadot, "Philosophy, Exegesis, and Creative Mistakes," 76.

87. Hadot, The Veil of Isis, 12.

88. "Il y a de nos jours des professeurs de philosophie, mais pas de philosophes . . ." Henry D. Thoreau, Cahiers de l'Herne (Paris: l'Herne, 1994), 191.

89. Hadot, The Present Alone is Our Happiness, 68. 
tion of philosophy as a way of life. In that sense, Foucault could be criticized for his anachronistic interpretations of Hellenistic philosophy: he projected latetwentieth-century aesthetic concerns onto the Hellenistic notion of the care of the self,,$^{90}$ he had little interest in philological issues, and he used outdated, unreliable editions of ancient texts. ${ }^{91}$ However, his disregard for context paradoxically allowed him to recapture something that was essential to the Hellenistic practice of philosophy: the individual appropriation of old texts for the purpose of living the good life. It should be added that, from Hadot's point of view, the historian's effort to achieve an objective understanding of past discourses could itself be seen as a spiritual exercise: "To study a text or microbes or the stars, one must undo oneself from one's own subjectivity." 92 Or, as Hadot put it in 2007, "objectivity is a result of the self working on the self (travail de soi sur soi). ${ }^{.93}$ In that sense, the historian of philosophy is like the Stoic philosopher who in his daily meditations tried to rise above his individual self in order to attain "the universality of the rational self." 94

In their 2001 conversation, Davidson asked Hadot the following fundamental question: "How to reconcile the objectivity, albeit probable, of the interpretation with the actual sense of a philosophical text?"95 (N.B.: In the question that was originally posed in French, actuel means current or present). Davidson went on to remind Hadot of the preface he wrote for the French translation of Ernst Bertram's book on Nietzsche. In it Hadot defined the writing of history as the coincidence of opposites:

The writing of history, indeed probably like all human activity, must be a coincidentia oppositorum by trying to respond to two equally urgent contradictory requirements. In order to perceive and evaluate historical reality, there must be, on the one hand, a conscious and total self-commitment, and on the other hand, an intended objectivity and impartiality. To my eyes, it is only the ascesis of scientific rigor, that self-detachment required for an objective and impartial judgment that will be able to give us the right to implicate ourselves in history, to give it an existential sense. ${ }^{96}$

In other words, the historian's task is to be totally objective and totally subjective at the same time. How this may happen is not totally clear. That Hadot chose to make these comments in a preface to Bertram is somewhat surprising, because Bertram's book is a striking example of what Hadot claims to detest in literary criticism and in the history of philosophy. Hadot begins his preface with a passionate endorsement: "I have often read and reread this book, and I have always found it new, unexpected, unique." ${ }^{97}$ Yet Bertram's book is deliberately allegorical (the subtitle is Attempt at a Mythology). It begins with this statement: "All the

90. "Reflections on the Idea of 'Cultivation of the Self'," in Hadot, Philosophy as a Way of Life, 206-213.

91. Hadot, The Present Alone is Our Happiness, 136.

92. Ibid., 66.

93. Davidson and Worms, ed., L'enseignement des antiques, l'enseignement des modernes, 29

94. Hadot, The Present Alone is Our Happiness, 67.

95. Ibid.

96. Ibid. Quoted from preface to Ernst Bertram, Nietzsche: Essai de mythologie, translated into French by Robert Pitrou, preface by Pierre Hadot (Paris: Editions du Félin, 2007), 34 (Nietzsche: Versuch einer Mythologie [Berlin: Georg Bondi, 1918]).

97. In Bertram, Nietzsche: Essai de mythologie, 5. 
past is but a parable," ${ }^{98}$ followed by the claim that "no historical method can give us a window on lived reality 'as it actually was,' as nineteenth-century advocates of a naïve historical realism so often seem to have believed." 99 Hadot explains that Bertram's opening sentence is "pregnant with meaning:" 100 Alles Gewesene ist nur ein Gleichnis (literally, "all that was is nothing but symbol") is an allusion to the conclusion of the second part of Goethe's Faust: Alles Vergängliche ist nur ein Gleichnis (literally, "all that passes is nothing but symbol"). And of course, as Bertram's American translator points out, the second sentence is an allusion to Ranke's oft-quoted passage on writing history wie es eigentlich gewesen ("as it actually was"). Bertram's Gleichnis (borrowed from Goethe) is a polemical response to Ranke's eigentlich: the symbolic against the real. As we have seen above, Hadot has no patience for those who overlook the letter of a text and claim "to decode and reveal the author's tacit meaning." Yet he approvingly describes Bertram's method as "psychoanalytic in the broad sense of the term," and leading to an exploration of Nietzsche's "imaginary" (imaginaire). ${ }^{101}$ He praises Bertram for having identified previously overlooked symbols that give us access to "the depth of Nietzsche's personality." 102 Hadot also insists that Bertram's interpretation, for all its "enthusiasm," ${ }^{103}$ is not arbitrary and relies constantly on Nietzsche's text without "forcing" or "over-interpreting" 104 it. In that sense, Bertram was still operating within the limits and guidelines of "the great historical school of the nineteenth century." 105 This is why Bertram represents an ideal coincidentia oppositorum: a historian who is both totally detached and totally engaged.

Still, Hadot is deeply critical of Bertram's philosophy of history. He dedicates several pages of the preface to a detailed description of Stefan George's circle as the context for understanding not only Bertram's work but also the approach to history and philology that is present in both Heidegger and Gadamer. He quotes from a little-known paper that Gadamer contributed to a 1985 colloquium on Stefan George and the sciences. ${ }^{106}$ In it Gadamer argues that George's fundamental contribution to historical method was the notion of Form (Gestalt). Intellectual biographies written by members of George's circle were Gestaltbiographen. Instead of telling the story of someone's life as a succession of events or an accumulation of influences, they looked for a Gestalt that presented a life as a coherent whole. Of course Bertram's book on Nietzsche is a brilliant example of this method. Aside from the opening lines we have seen above, there are few theoretical pronouncements in Bertram. Therefore, instead of directly criticizing Bertram, Hadot chooses to criticize two thinkers he sees as representing very similar philosophies

98. Ernst Bertram, Nietzsche: Attempt at a Mythology, transl. Robert E. Norton (Urbana: University of Illinois Press, 2009), 1. The French translation of Bertram's book by Pitrou was first published in 1932. There had been no English translation until 2009, presumably because of the Nazi sympathies Bertram expressed in the 1930 s.

99. Ibid.

100. In Bertram, Nietzsche: Essai de mythologie, 5.

101. Ibid., 19.

102. Ibid.

103. Ibid., 21.

104. Ibid.

105. Ibid.

106. Hans-Georg Gadamer, "Stefan George (1868-1933)," in Die Wirkung Stefan Georges auf die Wissenschaft: Ein Symposium, ed. H. J. Zimmermann (Heidelberg: C. Winter, 1985), 39-49. 
of history: Raymond Aron ${ }^{107}$ and Hans-Georg Gadamer. ${ }^{108}$ The association is not as odd as it might seem at first sight. Aron wrote his doctoral dissertation on the limits of historical objectivity ${ }^{109}$ after a stay in Germany during which he discovered Dilthey's philosophy of history. The members of his dissertation committee, who were all disciples of Durkheim, read Aron's work with deep suspicion and saw it as an attack on scientific method. ${ }^{110}$ As to Gadamer, in Truth and Method, he borrows heavily from Dilthey and criticizes him at the same time. ${ }^{11}$ Most importantly for the purposes of this study, Gadamer shows that Dilthey was fundamentally interested in describing historical phenomena as coherent and everexpanding wholes - a process culminating in the knowledge of universal history. In that sense his approach was hermeneutic: the whole derived its meaning from the parts, and each part derived its meaning from the whole "just as a word can be understood only in terms of the whole sentence, and the sentence fully understood only within the context of the whole text, indeed of the whole of literature." 112

This aspect is what Hadot is most fundamentally critical of. He greatly admires Bertram's book as a work of art that gives us profound insights into Nietzsche's personality, yet he sees the hermeneutic approach as a "regression" 113 that brings us back to pre-Enlightenment allegorical exegesis. In that sense any attempt to describe a person or an epoch as a coherent whole is allegorical and unscientific. At the same time, this regression recaptures the ancient and humanist tradition of historia magistra vitae, and the allegorical use of past events is consistent with the idea that truth does not come to life unless it is appropriated in a personal and individual way. ${ }^{114}$

In the end, Hadot's assessment of Bertram's work is a deeply ambivalent one. The coincidentia oppositorum can be seen in a strongly positive way. It carries mystical overtones and points to the Heraclitean notion of the unity of opposites. As Hadot puts it, an antithetical structure "reflects the very constitution of reality, in which contraries coincide." 115 It can also mean the coexistence of admirable qualities and unforgivable shortcomings. In Bertram, Hadot admires "the sophisticated construction, the monumentality, the poetry, the lofty inspiration, the vibrant sensitivity." ${ }^{116}$ At the same time, he is mindful of "the lyrical and frequently ponderous style, the total absence of footnotes to identify quotes, the massive and unsupported claims in the field of ancient religious history." 117

107. In Bertram, Nietzsche: Essai de mythologie, 20-21.

108. Ibid., 31-34.

109. Raymond Aron, Introduction à la philosophie de l'histoire: Essai sur les limites de l'objectivité historique, ed. Sylvie Mesure [1938] (Paris: Gallimard, 1986).

110. See ibid., presentation by Sylvie Mesure, ii-iv.

111. Hans-Georg Gadamer, Truth and Method, translation revised by Joel Weinsheimer and Donald G. Marshall (New York: Crossroad, 1992), 218-242 (Wahrheit und Methode [Tübingen: Mohr, 1960]).

112. Gadamer, Truth and Method, 231.

113. In Bertram, Nietzsche: Essai de mythologie, 33.

114. Ibid., 34.

115. Hadot, The Veil of Isis, 3.

116. In Bertram, Nietzsche: Essai de mythologie, 31.

117. Ibid. 
Hadot's most often quoted claim is that ancient philosophy was a life choice, and his support for this claim is based on careful, objective reconstruction of the context of ancient philosophical texts. In that sense, objective historical work is what gives us access to ancient philosophy as a form of life (to borrow an expression from Wittgenstein that Hadot also liked to use). But precisely, for us, the life of ancient philosophers is completely out of reach. As we have seen above, Hadot insists that "the meaning intended by the ancient author is never current (actuel). It is ancient, and that is all there is to it." 118 To us, these forms of life are dead, and Hadot does not subscribe to the Romantic belief that the past can be somehow brought back to life by the power of historical inquiry. The only way we can find spiritual nourishment in ancient philosophical texts and get something from them that sustains our lives is by ignoring their original context altogether. Only a deliberately presentist appropriation of ancient texts will make them existentially meaningful to us. Yet this exercise is even more violent than the allegory practiced by ancient and humanist philologists, who were often aware of historical difference and sought to bridge the gap between the truth claims found in ancient texts and the standards and expectations of the present. ${ }^{119}$

It may be argued that, far from being a "regression," Gadamer's philosophical hermeneutics is a deliberate and thoughtful reappropriation of the rhetorical tradition Hadot says had been forgotten. As Gadamer puts it, "Hermeneutic work is based on a polarity of familiarity and strangeness." 120 Texts from the past are strange and familiar at the same time, and "the true locus of hermeneutics is this in-between." 121 A good interpretation produces a point of view that is neither the reader's initial point of view nor the ancient author's, but a fusion of both, as happens between two parties in a successful conversation. If you say something and I say it back to you in my own words, it does not necessarily mean that I have betrayed it or turned it into something trivial. It may mean that you and I have come to an agreement about something. Hadot is mindful of the fact that Gadamer sought to recapture the spirit of Plato's dialectic in his hermeneutics. ${ }^{122} \mathrm{He}$ is, however, deeply skeptical about the success of this enterprise, and he notices that the conversations in George's circle were less conversations than lectures by the master to his adoring fans. ${ }^{123}$ This may well be a true account of George's circle, but Gadamer's hermeneutics does offer a solution to the puzzle of coincidentia oppositorum. For Gadamer, it is not necessary to be a radical presentist in order to extract living truths from ancient texts; conversely, a historical approach to ancient texts need not assume that these texts are dead letter, and the historically minded interpreter can be open to the possibility that some of the truth claims present in ancient texts might be valid. For Gadamer, "the call to leave aside the concepts of the present does not mean a naïve transposition into the past. It is, rather, an essen-

118. Hadot, The Present Alone is Our Happiness, 68 (translation modified).

119. See Kathy Eden, "Equity and the Origins of Renaissance Historicism: The Case for Erasmus," Yale Journal of Law and the Humanities 5 (1993), 137-45.

120. Gadamer, Truth and Method, 295.

121. Ibid.

122. In Bertram, Nietzsche: Essai de mythologie, 32.

123. Ibid. 
tially relative demand that has meaning only in relation to one's own concepts." ${ }^{124}$ The operative word in Gadamer's sentence is "relative" (but does not imply relativism). In order to avoid anachronistic interpretations, historians never cease to translate past languages into a language they can understand. As Gadamer puts it, "to think historically means, in fact, to perform the transposition that the concepts of the past undergo when we try to think in them." ${ }^{125}$ In that sense the life that animated ancient philosophical conversations is itself out of reach, but it is now present in the conversations we have with past philosophical texts.

Gadamer's approach is accommodative. It involves a "mediation" 126 between the ideas present in old texts and one's own thinking. Hadot, for his part, does not seem interested in seeking a middle ground. Translated into Gadamer's language, his position would consist in embracing absolute strangeness and absolute familiarity at the same time. This position may not be as idiosyncratic as it seems. With the caveat that "doctrinal comparisons" are rarely meaningful, one could see similarities between Hadot and Skinner, in addition to their common reliance on Wittgenstein. Like Hadot, Skinner in his more recent work jumps from strict contextualism to deliberately present-minded appropriations of classical political concepts. ${ }^{127}$ And like Hadot's 1968 article, Skinner's 1969 article on meaning and understanding in the history of ideas mocked the "mythology of coherence" 128 that affects the work of intellectual historians. What is almost unique to Hadot is the mystical dimension of his approach, which draws the ultimate consequences of a rhetorical understanding of philosophy as performance. For Hadot, if we take seriously the idea that philosophical texts matter less for what they say than for what they $d o$, after we have elucidated what they say, we should let them transform us and change our perception of the world. Interpretation yields to silent meditation or contemplation.

This mystical dimension is quite obvious in Hadot's later work (notably in The Veil of Isis), but it was arguably there from the very beginning. During Hadot's last public appearance in 2010, Frédéric Worms mentioned a 1942 issue of Fontaine edited by Jean Wahl on poetry as spiritual exercise, and suggested that it was an important early influence. Hadot replied that he remembered reading an article with this title, but did not remember it was by Jean Wahl. His recollection was correct. The article entitled "Poetry as Spiritual Exercise" 129 was written by Edmond Jaloux (1878-1949), a French academician known for his essays on German and English Romanticism. On the other hand, it is clear from reading the entire issue, including a short, untitled note by Wahl himself, ${ }^{130}$ that all the contributors had written on the topic at Jean Wahl's invitation and that the expression "poetry as spiritual exercise" was Wahl's. Two years later, Wahl published another

124. Gadamer, Truth and Method, 397.

125. Ibid.

126. Ibid.

127. See, for instance, Quentin Skinner, Liberty before Liberalism (Cambridge, UK: Cambridge University Press, 1998).

128. Skinner, "Meaning and Understanding in the History of Ideas," 16.

129. Edmond Jaloux, "La poésie exercice spirituel," Fontaine 19-20 (March-April 1942), 11-21.

130. Jean Wahl, "Note," Fontaine 19-20 (March-April 1942), 26-28. 
short piece in The Chimera entitled "On Poetry." 131 Written in the same spirit as the 1942 issue of Fontaine and referencing it, the piece defined poetry as a coincidentia oppositorum between commonplaces and individuality, and spoke about the convergence between philosophy and poetry, with references to Heraclitus, Whitehead, and Heidegger.

Clearly, there are many differences between Jean Wahl's philosophical agenda in the 1940s and the philosophical agenda that Hadot developed in later years. One must note, on the other hand, the staying power of expressions like spiritual exercise and coincidentia oppositorum. Good phrases are too hard for the teeth of time. Hadot's conversations with Wahl in the 1940s must have been about philosophy and poetry. During his last public appearance, Hadot indicated that he intended to write his doctoral dissertation on Heidegger and Rilke as "poets of existence," and that the inspiration for this topic came from Gabriel Marcel's work on Orphism. ${ }^{132}$ Why then did Hadot "defect" to the disenchanted realm of history and philology? As an immediate psychological explanation, one might invoke Hadot's desire to resist his own deep-seated inclination toward esoteric enthusiasm. A more philosophical explanation is that Hadot sought to give a deeper meaning to the expression coincidentia oppositorum. For him, the coincidence of opposites came to mean the coincidence between philosophy and history.

When Hadot gave his first talk on Wittgenstein at the Collège philosophique in 1959, he ended with a quote from the last pages of the Tractatus: "So too at death the world does not alter, but comes to an end." 133 Then, says Hadot, "there was an extraordinary silence: usually people in the audience shake their feet, clear their throats, or wiggle slightly. But the attention at that moment was intense."134 Similarly, the 2001 volume of conversations with Carlier and Davidson ends with a deliberate imitation of what Arrian did when he put together the Handbook of Epictetus: he left the reader with a series of quotes from various authors who summarized what he had meant to say. Thus Hadot's book ends with "a short, chronologically ordered anthology of texts ... about the sentiment of existence or the cosmic and 'oceanic' sentiment." 135 The very broad range of authors includes Zhuangzi, Seneca, Pascal, Blake, Goethe, Thoreau, Rilke, Wittgenstein, and Cézanne. "To comment on them," says Hadot, "would be to make them fade. They speak for themselves, and I propose them as a way to continue to communicate indirectly with my readers." 136

\section{Columbia University}

131. Jean Wahl, “On Poetry,” The Chimera 2, no. 3 (Winter-Spring 1944), 35-40.

132. See Gabriel Marcel, Homo Viator (Paris: Aubier, 1945). Also see Emmanuel Levinas, Xavier Tilliette, and Paul Ricoeur, Jean Wahl et Gabriel Marcel (Paris: Beauchesne, 1976).

133. Wittgenstein, Tractatus Logico-Philosophicus, transl. D. F. Pears and B. F. McGuiness (London: Routledge, 1961), §6.431.

134. Hadot, Wittgenstein et les limites du langage, 10.

135. Hadot, The Present Alone is Our Happiness, 177.

136. Ibid. 